\title{
Kontribusi Kepemimpinan Kepala Sekolah, Motivasi Kerja,dan Iklim Sekolah terhadap Kinerja Guru
}

\author{
Subandi \\ Administrasi Pendidikan, Program Pascasarjana, Universitas Pendidikan Ganesha, Indonesia
}

\section{Keywords:}

principal leadership;

work motivation;

school climate;

teacher performance

\section{Kata kunci:}

kepemimpinan kepala sekolah; motivasi kerja;

iklim sekolah;

kinerja guru

\begin{abstract}
This study aims at determining the contribution of school principal leadership, work motivation and school climate to the performance of elementary school teachers at Cluster IV District of Baturiti Tabanan Bali. This research was an ex-post facto research. The population which as also treated as the sample in this study were 61 teachers. Data in this study were collected by using questionnaires. Data analysis was performed by using simple regression, multiple regression, and partial correlation. The results showed that: (1) there was a significant contribution of headmaster leadership to the performance of elementary school teachers, (2) ) there is a significant contribution of teacher's work motivation to the performance of elementary school teacher; (3) there is significant contribution of work climate on the performance of elementary school teachers, and (4) together, there is a significant contribution of principal leadership, motivation work and work climate on the performance of elementary school teachers.
\end{abstract}

\begin{abstract}
Abstrak:Tujuan penelitian ini adalah mendeskripsikan kontribusi kepemimpinan kepala sekolah, motivasikerja, dan iklim sekolah terhadap kinerja guru SD se-Gugus IV Kecamatan BaturitiTabanan Bali. Penelitian ini adalah penelitian ex-post facto. Populasi yang sekaligus menjadi sampel dalam penelitian ini sebanyak 61 guru. Data pada penelitian ini dikumpulkan dengan kuesioner. Analisis data dilakukan dengan teknik regresi sederhana, regresi ganda, dan korelasi parsial. Hasil penelitian menunjukkan bahwa: (1) terdapat kontribusi yang signifikan kepemimpinan kepala sekolah terhadap kinerja guru, (2) terdapat kontribusi yang signifikan motivasi kerja guru terhadap kinerja guru, (3) terdapat kontribusi yang signifikan iklim kerja terhadap kinerja guru, dan (4) secara bersama-sama, terdapat kontribusi yang signifikan kepemimpinan kepala sekolah, motivasi kerja dan iklim kerja terhadap kinerja guru.
\end{abstract}

Alamat Korespondensi:

E-mail: subandi@pasca.undiksha.ac.id (Subandi)

\section{Pendahuluan}

Peningkatan mutu pendidikan merupakan sasaran pembangunan dibidang pendidikan nasional dan merupakan bagian yang tidak terpisahkan dari upaya peningkatan kualitas sumber daya manusia, mutu pendidikan dapat ditingkatkan jika proses belajar mengajar berlangsung secara efektif dan menyenangkan, dan peserta didik mengalami proses belajar yang bermakna dan ditunjang oleh adanya sarana prasarana yang memadai, sumber daya manusia (SDM) dan dana yang memadai.

Keberadaan sumber daya manusia dalam suatu organisasi dalam hal ini sekolah, memegang peranan yang sangat penting, sehingga harus bisa dimanfaatkan dengan sebaik-baiknya agar berdaya guna secara maksimal dan optimal, sumber daya manusia merupakan bagian dari suatu kemajuan ilmu, pembangunan dan teknologi, sumberdaya manusia yang kompeten yang memiliki semangat dan kedisiplinan yang tinggi dalam menjalankan peran dan fungsinya baik secara personal maupun secara organisasi.

Salah satu sumberdaya manusia yang memegang peranan penting dalam memajukan pendidikan nasional adalah guru, guru bertindak sebagai fasilitator dan mediator yang memungkinkan terciptanya lingkungan belajar yang kondusif bagi anak didiknya.Agar terciptanya lingkungan belajar yang kondusif, tentunya guru harus ekstra bekerja dengan baik.Namun realita di lapangan kerap ditemui yang bekerja kurang serius. Hal tersebut terlihat dari: 1) masih adanya guru yang lebih senang menggunakan suatu 
produk pembelajaran yang bersifat 'instan' daripada berlatih mendesain sendiri, dimana hal tersebut sebagai bukti belum teraktualisasinya kompetensi guru, 2) masih adanya guru yang lebih senang dan bangga menjadi satu-satunya sumber belajar tanpa berpikir perlunya berinteraksi dengan 'makhluk' lain selain dirinya. Menjadi pewarta materi dengan peserta didik yang duduk senang tanpa 'perlawanan', juga menjadi kebanggaannya., 3) masih adanya guru yang lebih senang menggunakan 'ancaman' untuk mengingatkan peserta didik daripada menerapkan teknik-teknik profesionalnya saat dididik menjadi guru sebelumnya, dan 4) juga terlihat adanya guru yang masih asing bahkan sinis terhadap inovasi tapi suka menganggukkan kepala tanda setuju tanpa memikirkan secara mendalam makna anggukan kepala tersebut.

Kinerja guru merupakan hal yang sangat penting dalam penunjang mutu pendidikan.King (1993:19) menyatakan bahwa kinerja adalah aktivitas seseorang dalam melaksanakan tugas pokok yang dibebankan kepadanya.Mengacu dari pandangan ini, dapat diinterpretasikan bahwa kinerja seseorang dihubungkan dengan tugas-tugas rutin yang dikerjakannya. Sebagai seorang guru misalnya, tugas rutinnya adalah melaksanakan proses belajar-mengajar di sekolah. Hasil yang dicapai secara optimal dari tugas mengajar itu merupakan kinerja seorang guru.

Berdasarkan pandangan ini dapat ditegaskan bahwa kinerja merupakan penjumlahan antara kemampuan dan motivasi kerja yang dimiliki seseorang.Dalam kaitannya dengan kinerja guru, kinerja mereka dapat terefleksi dalam tugasnya sebagai seorang pengajar dan seorang pelaksana administrator kegiatan mengajarnya. Atau dengan kata lain, kinerja guru dapat terlihat pada kegiatan merencanakan, melaksanakan, dan menilai proses belajar-mengajar yang intensitasnya dilandasi oleh etos kerja dan disiplin profesional guru.

Dalam meningkatkan kinerja guru, tentunya ada berbagai macam faktor yang harus diperhatikan. Faktor-faktor tersebut yakni: kepemimpinan kepala sekolah, motivasi kerja, dan iklim kerja tempat guru tersebut bekerja.George R Terry dan Leslie W.Rue, (2007:192) memandang "kepemimpinan sebagai kemampuan seseorang atau pemimpin, untuk mempengaruhi perilaku orang lain menurut keinginankeinginannya dalam suatu keadaan tertentu. Kepemimpinan adalah suatu pertumbuhan alami dari orangorang yang berserikat untuk suatu tujuan dalam kelompok." Kepemimpinan adalah setiap tindakan yang dilakukan oleh individu atau kelompok untuk mengkoordinasi dan memberi arah kepada individu atau kelompok lain yang tergabung dalam wadah tertentu untuk mencapai tujuan-tujuan yang telah ditetapkan sebelumnya (Danim, 2005:53)

Berdasarkan pemaparan tentang kepemimpinan di atas, seorang kepala sekolah hendaknya mampu memimpin guru-guru ataupun seluruh warga sekolah dengan baik.Sehingga guru-guru ataupun warga sekolah merasa nyaman dalam bekerja di sekolah.Selanjutnya, apabila seorang guru memiliki motivasi kerja yang baik, tentunya mereka akan bekerja dengan sungguh-sungguh dan bersemangat. Hal ini tentunya akan berdampak positif terhadap peningkatkan kinerja seorang guru. Sehingga dalam hal ini kepala sekolah maupun guru itu sendiri harus mampu untuk memotivasi dirinya untuk bekerja dengan baik.

Faktor terakhir adalah iklim kerja, iklim kerja sekolah adalah situasi atau suasana yang muncul karena adanya hubungan antara kepala skeolah dengan guru, guru dengan guru, guru dengan peserta didik atau hubungan antar peserta didik yang menjadi ciri khas sekolah yang ikut mempengaruhi proses belajar mengajar di sekolah (Tilaar, 2004;179). Iklim kerja di sekolah yang satu tidak sama dengan sekolah yang lain. Banyak faktor yang menjadi penyebab terjadinya perbedaan iklim kerja di sekolah, semuanya itu biasa disebut dengan kepribadian atau iklim sekolah.

Berdasarkan pemaparan di atas, maka dalam penelitian ini akan mengambil judul tentang kontribusi kepemimpinan kepala sekolah, motivasi kerja dan iklim sekolah terhadap kinerja guru SD seGugus IV Kecamatan Baturiti Tabanan Bali. Judul ini diambil karena belum pernah adanya penelitian yang meneliti permasalahan ini di SD se-Gugus IV Kecamatan Baturiti Tabanan Bali, sehingga peneliti ingin mengungkap seberapa besar kontribusi dari kepemimpinan kepala sekolah, motivasi kerja dan iklim sekolah terhadap kinerja guru SD se-Gugus IV Kecamatan Baturiti Tabanan Bali.

Berdasarkan latar belakang di atas, rumusan masalah yang diajukan dalam penelitian ini adalah (1) Apakah terdapat kontribusi yang signifikan kepemimpinan kepala sekolah terhadap kinerja guru SD se-Gugus IV Kecamatan Baturiti Tabanan Bali? (2) Apakah terdapat kontribusi yang signifikan motivasi kerja guru terhadap kinerja guru SD se-Gugus IV Kecamatan Baturiti Tabanan Bali? (3) Apakah terdapat kontribusi yang signifikan iklim kerja terhadap kinerja guru SD se-Gugus IV Kecamatan Baturiti Tabanan Bali? (4) Secara bersama-sama, Apakah terdapat kontribusi yang signifikan kepemimpinan kepala sekolah, motivasi kerja dan iklim kerja terhadap kinerja guru SD se-Gugus IV Kecamatan Baturiti Tabanan Bali? 


\section{Metode}

Penelitian ini termasuk penelitian ex-post fakto yang berbentuk korelasional. Termasuk dalam penelitian ex-post fakto karena variabel bebas dalam penelitian ini telah terjadi atau tidak dapat dimanipulasi. Tergolong penelitian korelasional karena penelitian yang dilakukan bermaksud untuk mengetahui kontribusi antara: (1) kepemimpinan kepala sekolah $\left(\mathrm{X}_{1}\right)$ terhadap kinerja guru SD se-Gugus IV Kecamatan Baturiti Tabanan Bali(Y), (2) motivasi kerja $\left(\mathrm{X}_{2}\right)$ terhadap kinerja guru SD se-Gugus IV Kecamatan Baturiti Tabanan Bali $(Y)$, (3) iklimkerja $\left(\mathrm{X}_{3}\right)$ terhadap kinerja guru SD se-Gugus IV Kecamatan Baturiti Tabanan Bali (Y), dan (4) kepemimpinan kepala sekolah $\left(\mathrm{X}_{1}\right)$, motivasi kerja $\left(\mathrm{X}_{2}\right)$, dan iklimkerja $\left(\mathrm{X}_{3}\right)$ secara bersama-sama terhadap kinerja guru SD se-Gugus IV Kecamatan Baturiti Tabanan Bali (Y).

Dalam situasi ex-post facto, peniliti tidak dapat mengontrol variabel bebas melalui manipulasi atau randomisasi.Istilah ex-post facto menunjukkan bahwa perubahan-perubahan dalam variabel bebas telah terjadi begitu adanya. Oleh karena itu, peneliti menghadapi masalah untuk mencoba menentukan penyebab dari akibat yang terlihat, dan tidak semestinya peneliti secara sembarangan menyimpulkan bahwa ada hubungan murni antara X dan Y dalam study ex-post facto (Dantes, 2012:60).

Sugiyono (2016:119) menyatakan bahwa populasi adalah wilayah generalisasi yang terdiri atas objek dan subjek yang mempunyai kualitas dan karakteristik tertentu yang ditetapkan oleh peneliti untuk dipelajari dan kemudian ditarik kesimpulannya. Sedangkan Agung (2014;69) menyatakan populasi adalah keseluruhan objek dalam suatu penelitian. Populasi dalam penelitian ini adalah semua guru-guru SD / MI Gugus IV Kecamatan Baturiti Kabupaten Tabanan, dari hasil pra survey diperoleh data informasi bahwa jumlah guru yang ada di Gugus IV adalah 61 guru.

Agung (2016;8) menyatakan bahwa sampel merupakan bagian dari populasi yang secara langsung dikenai penelitian. Dikarenakan jumlah populasi yang tidak terlalu banyak, sehingga dalam penelitian ini menggunakan seluruh populasi menjadi sampel penelitian.Maka dari itu, sampel dalam penelitian ini berjumlah 61 orang guru.

Variabel pada penelitian ini dapat dibedakan menjadi dua yaitu variabel bebas (independent variabel) dan variabel terikat (dependent variabel). Variabel bebas (X) merupakan variabel faktor, faktor yang diduga berpengaruh terhadap variabel terikat. Variabel yang disebutkan sebagai variabel bebas (X) dalam penelitian ini adalah kepemimpinan kepala sekolah $\left(\mathrm{X}_{1}\right)$, motivasi kerja $\left(\mathrm{X}_{2}\right)$ iklim $\operatorname{kerja}\left(\mathrm{X}_{3}\right)$ sedangkan sebagai variabel terikat (Y) dalam penelitian ini adalah kinerja guru.

Instrument adalah alat ukur yang digunakan untuk memperoleh data tentang variabel. Arikunto (2005; 62) mengatakan bahwa instrument merupakan alat bantu bagi peneliti dalam menggunakan metode pengumpulan data. Metode selain untuk menggumpulkan data, juga dapat digunakan untuk mengukur variabel. Instrument utama dalam penelitian ini adalah kuesioner.

Informasi yang dicari dalam penelitian ini adalah: 1) kepemimpinan kepala sekolah, motivasi kerja, iklim kerja serta gambaran umum kinerja guru. Gambaran umum tersebut berupa skor rata-rata, simpangan baku, skor terendah, skor tertinggi, modus, dan median, 2) model regresi antara tiga variabel bebas dan variabel terikat baik sendiri-sendiri maupun bersama-sama, 3) koefisien regresi dari masingmasing model regresi, digunakan untuk meramal atau menaksir besarnya variansi nilai Y (variabel terikat), dan 4) korelasi parsial digunakan untuk menentukan hubungan murni antara satu variabel bebas dengan variabel terikat, dengan mengendalikan variabel bebas lainnya.

Kegiatan analisis data terdiri atas kegiatan pengolahan data dan analisis statistik. Kegiatan analisis data meliputi: 1) menyunting data secara manual. Penyuntingan dilakukan karena kemungkinan ada data yang tidak jelas, atau kesalahan dalam pengisian instrument, sehingga tidak memenuhi syarat untuk dianalisis, 2) mentabulasi data, dan 3) mengolah data dalam bentuk sesuai kebutuhan.

Untuk menguji hipotesis yang telah dirumuskan, terlebih dahulu dilakukan analisis data yang telah dikumpulkan. Dalam melakukan analisis data untuk penelitian ini dilakukan dengan tiga tahapan yakni: 1) tahap analisis statistik deskriptif, 2) tahap pengujian persyarat analisis, 3) tahap pengujian hipotesis.

Hipotesis yang diuji dalam penelitian ini adalah sebagai berikut.

1) Terdapat kontribusi yang signifikan kepemimpinan kepala sekolah terhadap kinerja guru SD se-Gugus IV Kecamatan Baturiti Tabanan Bali.

2) Terdapat kontribusi yang signifikan motivasi kerja guru terhadap kinerja guru SD se-Gugus IV Kecamatan Baturiti Tabanan Bali.

3) Terdapat kontribusi yang signifikan iklim kerja terhadap kinerja guru SD se-Gugus IV Kecamatan Baturiti Tabanan Bali.

4) Secara bersama-sama, terdapat kontribusi yang signifikan kepemimpinan kepala sekolah, motivasi kerja dan iklim kerja terhadap kinerja guru SD se-Gugus IV Kecamatan Baturiti Tabanan Bali. 
Untuk menguji hipotesis pertama, kedua, dan ketiga digunakan teknik analisis korelasi sederhana (korelasi product moment pearson). Untuk menguji hipotesis ke empat, digunakan teknik analisis korelasi ganda, regresi ganda, dan korelasi parsial.

\section{Hasil dan Pembahasan}

\section{1) Terdapat kontribusi yang signifikan kepemimpinan kepala sekolah terhadap kinerja guru SD se-Gugus IV Kecamatan Baturiti Tabanan Bali}

Hipotesis pertama menyatakan bahwa terdapat kontribusi yang signifikan kepemimpinan kepala sekolah terhadap kinerja guru SD se Gugus IV Kecamatan Baturiti Tabanan Bali.Pengujian hipotesis ini dilakukan dengan teknik korelasi dan regresi linier sederhana.Hasil perhitungan regresi sederhana $Y$ atas X1, ditemukan persamaan regresi $\hat{y}=123,029+0,607 X 1$ dengan Freg $=33,285$ serta kontribusi sebesar $36,10 \%$ adalah signifikan dan linier. Karena Freg > Ftabel. Berdasarkan analisis dengan komputer korelasi antara kepemimpinan kepala sekolah (X1) dengan Kinerja guru (Y) diperoleh $r_{\text {hitung }}=0,601$. Ini berarti $r_{\text {hitung }}=0,601$ signifikan pada $\alpha=0,05\left(r_{\text {tabel }}=0,254\right)$. Dengan demikian hipotesis nol (H0) yang menyatakan "tidak terdapat kontribusi yang signifikan kepemimpinan kepala sekolah terhadap kinerja guru SD se Gugus IV Kecamatan Baturiti Tabanan Bali" ditolak.Hal ini berarti hipotesis penelitian (Ha) yang diajukan yaitu "terdapat kontribusi yang signifikan kepemimpinan kepala sekolah terhadap kinerja guru SD se Gugus IV Kecamatan Baturiti Tabanan Bali" diterima.

Hasil penelitian ini sejalan dengan hasilpenelitian yang dilakukan oleh Yasmini (2017) yang berjudul Kontribusi Gaya Kepemimpinan Kepala Sekolah, Kompetensi Profesional dan Motivasi Kerja Guru Terhadap Kinerja Guru-Guru Sekolah Dasar di Kecamatan Kuta Utara. Dalam penelitiannya dinyatakan bahwa 1) terdapat kontribusi yang signifikan gaya kepemimpinan kepala sekolah terhadap kinerja guru-guru sekolah dasar di Kecamatan Kuta Utara, 2) terdapat kontribusi yang signifikan kompetensi profesional terhadap kinerja guru-guru sekolah dasar di Kecamatan Kuta Utara, 3) terdapat kontribusi yang signifikan motivasi kerja guru terhadap kinerja guru-guru sekolah dasar di Kecamatan Kuta Utara, dan 4) terdapat kontribusi yang signifikan secara bersama-sama gaya kepemimpinan kepala sekolah, kompetensi profesional dan motivasi kerja guru terhadap kinerja guru-guru sekolah dasar di Kecamatan Kuta Utara.

Secara umum Tim Administrasi Pendidikan UPI (dalam Susanto, 2016:5) merumuskan definisi kepemimpinan sebagai kemampuan dan kesiapan untuk dapat mempengaruhi, mendoro, mengajak, menuntun, menggerakkan, mengarahkan, dan kalau perlu memaksa orang atau kelompok agar menerima pengaruh tersebut dan selanjutnya berbuat sesuatu yang dapat membantu tercapainya suatu tujuan tertentu yang telah ditetapkan. Sedangkan Sudarwan Danim (Susanto, 2016: 5) menjelaskan bahwa kepemimpinan adalah kemampuan mengambil inisiatif dalam situasi sosial untuk menciptakan bentuk dan prosedur baru, merancang, dan mengatur perbuatan, dan dengan berbuat begitu membangkitkan kerja sama kearah tercapainya tujuan.

Proses kepemimpinan merupakan proses yang interaktif dan dinamis dalam mempengaruhi orang lain, dalam proses tersebut seorang pemimpin harus memiliki dasar kemampuan serta terampil dalam menggerakkan bawahannya agar dapat bekerja secara maksimal (Suharsaputra, 2016;21).Menurut Natajaya (2012: 92) bahwa kepemimpinan tersebut menunjukkan bahwa dalam kepemimpinan tersebut paling tidak mencakup tiga hal yang saling berkaitan, yaitu: adanya pemimpin dan karakteristiknya, adanya bawahan, serta adanya situasi dalam kelompok tempat pemimpin dan bawahan saling berinteraksi. Berdasarkan pemaparan tersebut, seorang kepala sekolah hendaknya mampu memimpin guru-guru ataupun seluruh warga sekolah dengan baik. Sehingga guru-guru ataupun warga sekolah merasa nyaman dalam bekerja di sekolah dan kinerja guru pun dapat ditingkatkan secara optimal.

\section{2) Terdapat kontribusi yang signifikan motivasi kerja guru terhadap kinerja guru SD se-Gugus IV Kecamatan Baturiti Tabanan Bali}

Hipotesis kedua menyatakan ada kontribusi yang signifikan antara motivasi kerja terhadap kinerja guru SD se Gugus IV Kecamatan Baturiti Tabanan Bali.Pengujian hipotesis ini dilakukan dengan teknik korelasi dan regresi sederhana.Hasil perhitungan regresi sederhana $\mathrm{Y}$ atas $\mathrm{X} 2$, ditemukan persamaan regresi $\hat{y}=72,843+0,872 X 2$ dengan Freg $=30,893$ serta kontribusi sebesar $34,40 \%$ adalah signifikan dan linier. Berdasarkan analisis dengan komputer, korelasi antara motivasi kerja (X2) dengan kinerja guru ( $\mathrm{Y}$ ) diperoleh $\mathrm{r}_{\text {hitung }}=0,586$. Ini berarti $\mathrm{r}_{\text {hitung }}=0,586$ signifikan pada $\alpha=0,05\left(\mathrm{r}_{\text {tabel }}=0,254\right)$. Dengan demikian hipotesis nol (H0) yang menyatakan "tidak terdapat kontribusi yang signifikan motivasi kerja terhadap kinerja guru SD se Gugus IV Kecamatan Baturiti Tabanan Bali" ditolak.Hal ini berarti hipotesis penelitian (Ha) yang diajukan yaitu "terdapat kontribusi yang signifikan motivasi kerja terhadap kinerja guru SD se Gugus IV Kecamatan Baturiti Tabanan Bali" diterima. 
Hasil penelitian ini sejalan dengan hasilpenelitian yang dilakukan oleh Erayati (2017) yang berjudul Hubungan Supervisi Akademik, Motivasi Kerja Guru, Kompetensi Pedagogik dengan Kinerja Guru SMA Negeri 1 Kediri Tabanan. Dalam penelitiannya dinyatakan bahwa: 1) terdapat Hubungan yang signifikan antara supervisi akademik dengan kinerja guru SMA Negeri 1 Kediri Tabanan, 2) terdapat hubungan yang signifikan antara motivasi kerja guru dengan kinerja guru SMA Negeri 1 Kediri Tabanan, 3) terdapat hubungan yang signifikan antara kompetensi pedagogik dengan kinerja guru SMA Negeri 1 Kediri Tabanan, dan 4) terdapat hubungan yang signifikan secara bersama-sama antara supervisi akademik, motivasi kerja guru, kompetensi pedagogik dengan kinerja guru SMA Negeri 1 Kediri Tabanan.

Menurut Siagian (2008:138), mengemukakan bahwa :"Motivasi adalah daya pendorong yang mengakibatkan seseorang anggota organisasi mau dan rela untuk menggerakkan kemampuan dalam membentuk keahlian dan keterampilan tenaga dan waktunya untuk menyelenggarakan berbagai kegiatan yang menjadi tanggung jawabnya dan menunaikan kewajibannya dalam rangka pencapaian tujuan dan berbagai sasaran organisasi yang telah ditentukan sebelumnya.

Menurut Robbins (dalam Tambunan, 2015:194) berpendapat bahwa motivasi adalah kesediaan untuk mengeluarkan tekad upaya yang tinggi ke arah tujuan organisasi, yang dikondisikan oleh kemampuan upaya itu untuk memenuhi sesuatu kebutuhan individual.Kebutuahan adalah keadaan batin yang membuat hasil-hasil tertentu tampak menarik.Sedangkan Culligan (dalam Tambunan, 2015:195)memberi pengertian motivasi adalah dorongan batin seseorang yang menggerakannya untuk bertindak memenuhi sasaran-sasaran dan kebutuhan.Untuk mengelola motivasi, harus memahami "bagaiman" dan "mengapa-nya" interaksi manusia. Dengan memahami interaksi manusia, maka akan mampu membentuk (dan mengubah) sikap-sikap dan pendapat, merangsang kreativitas, menolong anak buah untuk belajar dan berkembang mengelola konflik secara produktif, dan menguasai sekumpulan topik lain yang dibutuhkan bagi interaksi dan kepemimpinan manusia yang efektif.

Dengan demikian, berdasarkan pandangan-pandangan tersebut di atas, dapat dikatakan bahwa motivasi adalah faktor internal seseorang yang sangat mempengaruhi kulitas kinerja orang tersebut.Semakin baik motivasi yang dimiliki, tentunya semakin baik pula kinerja yang ditunjukkan.

Apabila seorang guru memiliki motivasi kerja yang baik, tentunya mereka akan bekerja dengan sungguh-sungguh dan bersemangat. Hal ini tentunya akan berdampak positif terhadap peningkatkan kinerja seorang guru. Sehingga dalam hal ini kepala sekolah maupun guru itu sendiri harus mampu untuk memotivasi dirinya untuk bekerja dengan baik.

\section{3) Terdapat kontribusi yang signifikan iklim kerja terhadap kinerja guru SD se-Gugus IV Kecamatan Baturiti Tabanan Bali}

Hipotesis ketiga menyatakan bahwa terdapat kontriubusi yang signifikan antara iklim sekolah terhadap kinerja guru SD se Gugus IV Kecamatan Baturiti Tabanan Bali.Pengujian hipotesis ini dilakukan dengan teknik korelasi dan regresi sederhana. Hasil perhitungan regresi sederhana $\mathrm{Y}$ atas X3, ditemukan persamaan regresi $\hat{y}=88,529+0,825 X 3$ dengan Freg $=51,697$ serta kontribusi sebesar $46,70 \%$ adalah signifikan dan linier. Hal itu dikarenakan Freg > Ftabel. Berdasarkan analisis dengan komputer, korelasi antara iklim sekolah (X3) dengan kinerja guru (Y) diperoleh $r_{\text {hitung }}=0,683$. Ini berarti $r_{\text {hitung }}=0,683$ signifikan pada $\alpha=0,05\left(\mathrm{r}_{\text {tabel }}=0,254\right)$. Dengan demikian hipotesis nol (H0) yang menyatakan "tidak terdapat kontriubusi yang signifikan iklim sekolah terhadap kinerja guru SD se Gugus IV Kecamatan Baturiti Tabanan Bali" ditolak.Hal ini berarti hipotesis penelitian (Ha) yang diajukan yaitu "terdapat kontriubusi yang signifikan iklim sekolah terhadap kinerja guru SD se Gugus IV Kecamatan Baturiti Tabanan Bali" diterima.

Hasil penelitian ini sejalan dengan hasil penelitian yang dilakukan oleh Adi (2015) yang berjudul Kontribusi Perilaku Kepemimpinan Kepala Sekolah, Iklim Kerja dan Etos kerja Terhadap Kinerja Guru Bimbingan Konseling Pada SMA Se Kabupaten Tabanan. Dalam penelitiannya dinyatakan bahwa: (1) terdapat kontribusi yang positif dan signifikan antara perilaku kepemimpinan kepala sekolah terhadap kinerja guru bimbingan konseling sebesar 18,4\%, (2) terdapat kontribusi yang positif dan signifikan antara iklim kerja terhadap kinerja guru bimbingan konseling, sebesar 49,5\%, (3) terdapat kontribusi yang positif dan signifikan antara etos kerja terhadap kinerja guru bimbingan konseling sebesar 34,8\% (4) secara bersama-sama terdapat kontribusi yang positif dan signifikan antara perilaku kepemimpinan kepala sekolah, iklim kerja dan etos kerja terhadap kinerja guru bimbingan konseling pada SMA se kabupaten Tabanan, dengan kontribusi sebesar 51,4\%, Dari paparan hasil diatas, maka dapat disimpulkan bahwa ketiga variabel tersebut dapat dijadikan prediktor kecendrungan kinerja perilaku kepemimpinnan kepala sekolah, iklim kerja dan etos kerja terhadap kinerja guru bimbingan konseling pada SMA se kabupaten Tabanan.

Iklim kerja sekolah adalah situasi atau suasana yang muncul karena adanya hubungan antara kepala skeolah dengan guru, guru dengan guru, guru dengan peserta didik atau hubungan antar peserta 
didik yang menjadi ciri khas sekolah yang ikut mempengaruhi proses belajar mengajar di sekolah (Tilaar, $2004 ; 179)$.

Hoy dan Miskel (2001:216) mengemukakan bahwa terdapat tingkah laku di dalam setiap organisasi mempunyai fungsi yang tidak sederhana karena di dalamnya terdapat sejumlah kebutuhan individu-individu dan tujuan-tujuan organisasi yang ingin dicapai bersama. Hubungan-hubungan antara unsur di dalamnya sangatlah dinamis, mereka membawa kebiasaan-kebiasaan unik dan rumah masingmasing dengan segala simbul, nilai-nilai dan motivasi.

Aktivitas yang dilakukan oleh manusia dapat berjalan dengan baik jika situasi dan kondisinya mendukung serta memungkinkan aktivitas itu terlaksana. Dengan demikian dapat disimpulkan bahwa kondisi lingkungan kerja akan iklim kerja pada suatu organisasi sekolah harus diciptakan dengan sedemikian rupa sehingga guru merasa nyaman dalam melaksanakan tugas pokok dan fungsinya. Lingkungan atau iklim kondusif akan mendorong guru untuk lebih berprestasi optimal sesuai dengan minat dan kemampuannya.

Stol (dalam Supardi, 2014:122) menyatakan bahwa "iklim sekolah yang positif dan kondusif dapat membentuk peserta didik berberlakuan baik dan prestasi akademiknya meningkat". Sedangkan Susanto (2016:179) iklim organisasi sekolah adalah lingkungan manusia di mana para guru melakukan pekerjaan mereka atau serangkaian sifat lingkungan kerja yang dinilai langsung atau tidak langsung oleh guru yang dianggap menjadi kekuatan utama dalam mempengaruhi perilaku guru.

Berdasarkan pemaparan di atas, dapat disimpulkan bahwa apabila iklim kerja sekolah sudah kondusif, tentunya guru akan merasa nyaman dan aman dalam bekerja, sehingga kinerja guru pun dapat ditingkatkan secara optimal.

\section{4) Secara bersama-sama, terdapat kontribusi yang signifikan kepemimpinan kepala sekolah, motivasi kerja} dan iklim kerja terhadap kinerja guru SD se-Gugus IV Kecamatan Baturiti Tabanan Bali

Hipotesis keempat menyatakan bahwa secara bersama-sama, terdapat kontribusi yang signifikan antara kepemimpinan kepala sekolah, motivasi kerja, dan iklim sekolah terhadap kinerja guru SD se Gugus IV Kecamatan Baturiti Tabanan Bali. Pengujian perhitungan regresi ganda diperoleh persamaan garis regresi $\hat{y}=15,640+0,308 X 1+0,511 X 2+0,482 X 3$ dengan Freg $=36,366(p<0,05)$ adalah signifikan dengan kontribusi ( $R$ square $x$ 100) sebesar 65,70\%. Dengan demikian hipotesis nol (H0) yang menyatakan "Secara bersama-sama, tidak terdapat kontribusi yang signifikan kepemimpinan kepala sekolah, motivasi kerja, dan iklim sekolah terhadap kinerja guru SD se Gugus IV Kecamatan Baturiti Tabanan Bali" ditolak.Hal ini berarti hipotesis penelitian (Ha) yang diajukan, yaitu "Secara bersama-sama, terdapat kontribusi yang signifikan antara kepemimpinan kepala sekolah, motivasi kerja, dan iklim sekolah terhadap kinerja guru SD se Gugus IV Kecamatan Baturiti Tabanan Bali" diterima.

Kinerja guru merupakan hal yang sangat penting dalam penunjang mutu pendidikan.Prawirosentono (1992:2) mengartikan kinerja atau performance adalah hasil kerja yang dapat dicapai oleh seseorang atau sekelompok orang dalam suatu organisasi sesuai dengan wewenang dan tanggung jawabnya, dalam rangka mencapai tujuan organisasi. Disebutkan pula beberapa faktor yang perlu diketahui sehubungan dengan penilaian kinerja bawahan yaitu : (1) pengetahuan tentang pekerjaan, (2) kemampuan membuat perencanaan, (3) pengetahuan standar mutu pekerjaan, (4) produktivitas karyawan, (5) pengetahuan teknis atas karyawan, (6) kemandirian dalam melaksanakan tugas, (8) kemampuan bekerjasama. Apabila seorang guru menunjukkan kinerja yang baik, tentunya akan berdampak positif terhadap peningkatkan kemampuan peserta didiknya.

Whitmore (dalam Uno, et.al., 2001:99) mengungkapkan bahwa kinerja adalah suatu perbuatan, suatu prestasi atau apa yang diperlihatkan seseorang melalui keterampilan yang nyata. Pengertian ini menuntut tergambarnya tanggung jawab yang besar dari pekerjaan seseorang. Menurutnya kinerja yang nyata jauh melampaui apa yang diharapkan adalah kinerja yang menetapkan standar-standar tertinggi dari seseorang. Kinerja seperti inilah yang sering diminta atau diharapkan orang lain.

Dalam meningkatkan kinerja guru, tentunya ada berbagai macam faktor yang harus diperhatikan. Faktor-faktor tersebut yakni: kepemimpinan kepala sekolah, motivasi kerja, dan iklim kerja tempat guru tersebut bekerja. Ketiga faktor tersebut tidak bisa dipisahkan satu sama lain. Hal itu dikarenakan ketiga faktor tersebut merupakan sebuah sistem yang ada pada diri guru dan lingkungan tempat guru bekerja.

Dalam penelitian ini, didapatkan hasil bahwa ketiga faktor tersebut memberikan kontribusi yang signifikan terhadap kinerja guru. Sehingga ketiga faktor tersebut dapat dijadikan prediksi dalam meningkatkan kinerja guru.Implikasi yang diberikan dari diadakannya penelitian ini bagi guru adalah menambah wawasan tentang kinerja guru dalam bekerja, sehingga pada akhirnya dapat digunakan sebagai acuan untuk melaksanakan kewajiban dengan sebaik-baiknya dan kinerja guru pun dapat ditingkatkan. 
Implikasi yang diberikan dari diadakannya penelitian ini bagi kepala sekolah adalah membantu kepala sekolah untuk dapat melaksanakan tugas dengan baik, sesuai dengan tugas dan wewenang kepala sekolah yang salah satunya adalah mengkoordinasikan sumber daya manusia untuk dapat bekerja semaksimal dalam mencapai tujuan sekolah.Implikasi yang diberikan dari diadakannya penelitian ini bagi sekolah adalah: sekolah menjadi memiliki bahan untuk merefleksi diri sehingga permasalahan yang dihadapi sekolah dalam rangka meningkatkan kinerja guru dapat diminimalkan.

\section{Simpulan}

Berdasarkan temuan-temuan yang didapatkan pada penelitian ini, maka dapat disimpulkan sebagai berikut.

1) Terdapat kontribusi yang signifikan kepemimpinan kepala sekolah terhadap kinerja guru SD se-Gugus IV Kecamatan Baturiti Tabanan Bali dengan Freg = 33,285, kontribusi sebesar 36,10\%, dan sumbangan efektif sebesar $18,29 \%$.

2) Terdapat kontribusi yang signifikan motivasi kerja guru terhadap kinerja guru SD se-Gugus IV Kecamatan Baturiti Tabanan Balidengan Freg $=30,893$, kontribusi sebesar 34,40\%, dan sumbangan efektif sebesar $20,15 \%$.

3) Terdapat kontribusi yang signifikan iklim kerja terhadap kinerja guru SD se-Gugus IV Kecamatan Baturiti Tabanan Balidengan Freg $=51,697$, kontribusi sebesar 46,70\% dan sumbangan efektif sebesar $27,30 \%$.

4) Secara bersama-sama, terdapat kontribusi yang signifikan kepemimpinan kepala sekolah, motivasi kerja dan iklim kerja terhadap kinerja guru SD se-Gugus IV Kecamatan Baturiti Tabanan Balidengan Freg $=36,366(p<0,05)$ dan kontrubusi/sumbangan efektif sebesar $65,70 \%$.

\section{Referensi}

Adi, Ni Made Asricita. (2015). Kontribusi Perilaku Kepemimpinan Kepala Sekolah, Iklim Kerja dan Etos kerja Terhadap Kinerja Guru Bimbingan Konseling Pada SMA Se Kabupaten Tabanan. E-Jurnal Pascasarjana Undiksha Volume 6 Nomor 1.

Agung, A. A G. (2016). Statistika Dasar Untuk Pendidikan. Yogyakarta: Deepublish.

Agung, A. A. G. (2014). Metodologi Penelitian Pendidikan. Malang: Aditya Media Publishing.

Arikunto, S. (2005). Manajeman Penelitian. Jakarta: Rineka Cipta.

Danim, Sudarman (2005). Motivasi Kepemimpinan dan Efektivitas Kelompok. Penerbit Rineka Cipta

Dantes, Nyoman. (2012). Metode Penelitian. Yogyakarta; Andi Offset.

Erayati, Ni Kadek Dwipa. (2017). Hubungan Supervisi Akademik, Motivasi Kerja Guru, Kompetensi Pedagogik dengan Kinerja Guru SMA Negeri 1 Kediri Tabanan. E-Jurnal Pascasarjana Undiksha Volume 8 Nomor 1.

Hoy, Wayne K. \& Miskel, Cecil G. (2001). Educational Administration Theory, Research, And Practice 6th ed., International Edition. Singapore: McGraw-Hill Co.

Natajaya I Nyoman. (2012). Problema Pendidikan. Singaraja: Universitas Pendidikan Ganesha

Prawirosentono, Suyudi. (1992). Kebijakan Kinerja Karyawan : Kiat Membangun Organisasi Kompetitif Menjelang Perdagangan Bebas Dunia. Yogyakarta; BPFE.

Siagian, Sondang P. (2008). Teori dan Praktek Kepemimpinan. Jakarta: Rineka Cipta.

Sugiyono. (2016). Metode Penelitian Pendidikan (Pendekatan Kuantitatif, Kualitatif dan R\&D). Penerbit CV. Alfabeta: Bandung.

Suharsaputra, Uhar. (2016). Kepemimpinan Inovasi Pendidikan. Bandung; Refika Aditama.

Supardi. (2014). Kinerja Guru. Jakarta: Rajawali Pers.

Susanto, Ahmad. (2016). Manajemen Peningkatan Kinerja Guru. Jakarta: Prenadamedia Group.

Tambunan, Toman Sony. (2015). Pemimpin dan Kepemimpinan.Yogyakarta: Graha Ilmu.

Terry, George R. dan Leslie W. Rue. (2007). Dasar-Dasar Manajemen. Jakarata: Bumi Aksara.

Tilaar. (2004). Paradigma Baru Pendidikan nasional. Jakarta: Grasindo.

Uno, Hamzah B, dkk. (2001). Pengembangan Instrumen untuk Penelitian. Jakarta: Delima Pess.

Yasmini, Sayu Ketut. (2017). Kontribusi Gaya Kepemimpinan Kepala Sekolah, Kompetensi Profesional dan Motivasi Kerja Guru Terhadap Kinerja Guru-Guru Sekolah Dasar di Kecamatan Kuta Utara. EJurnal Pascasarjana Undiksha Volume 8 Nomor 1. 